\title{
Insulin activates Stat3 independently of p21ras-ERK and PI-3K signal transduction
}

\author{
Paul J Coffer ${ }^{1,2}$, André van Puijenbroek ${ }^{2}$, Boudewijn MTh Burgering ${ }^{3}$, Marjolijn Klop-de Jonge ${ }^{2,3}$, \\ Leo Koenderman ${ }^{1}$, Johannes L Bos ${ }^{3}$ and Wiebe Kruijer ${ }^{4}$ \\ ${ }^{1}$ Department of Pulmonary Diseases, G03.550, University Hospital Utrecht, Heidelberglaan 100, 3584 CX Utrecht; ${ }^{2}$ Hubrecht \\ Laboratory, Uppsalalaan 8, 3584 CT Utrecht; ${ }^{3}$ Laboratory for Physiological Chemistry, Utrecht University, Universiteitsweg 100, \\ 3584 CG Utrecht; ${ }^{4}$ Department of Genetics, University of Groningen, Biological Centre, PO Box 14, 9750 AA Haren, The \\ Netherlands
}

The binding of insulin to its receptor initiates multiple signal transduction pathways regulating such diverse processes as proliferation, differentiation, glucose transport, and glycogen metabolism. The STAT-family of transcription factors has been demonstrated to play a critical role in gene induction by a variety of hemopoietic cytokines and hormones. Furthermore, constitutive activation of STATs is observed in transformed cells. Here we describe activation of a transcriptional complex binding to a consensus STAT-transcriptional element in response to insulin challenge. This complex is induced rapidly after tyrosine autophosphorylation of the insulin receptor, and is sustained for several hours. Supershift analysis of the insulin-induced complex reveals that it specifically contains the transcription factor Stat3. DAN binding of this complex is inhibited by pre-incubation with tyrosine, but not serine/threonine protein kinase inhibitors, whereas transcriptional activation is inhibited by both. Utilising a dominant negative mutant of p21ras we demonstrate that both insulin-induced Stat3 DNAbinding and also transactivation do not require p21ras. Furthermore, although previous studies have suggested a role for MAP kinases (ERKs) and PI-3K in STAT activation, utilising the specific MEK inhibitor PD098059 and the PI-3K inhibitor wortmannin, we demonstrate that activation of ERKs or PI-3K are not required for insulin induced Stat3 phosphorylation or transactivation.

Keywords: Insulin; STAT; Ras; ERK; PI-3K

\section{Introduction}

Challenge of target cells with insulin results in a pleiotropic response that can include cellular proliferation or differentiation, stimulation of amino acid and hexose uptake, glycogen metabolism, and induction of mRNA and protein synthesis (Rosen, 1987; Roth et al., 1992; Medema and Bos, 1993; Lee and Pilch, 1994). These effects are initiated by the interaction of insulin with its high affinity cell surface receptor followed by autophosphorylation, a critical step since kinaseinactive receptor mutants are unable to mediate many cellular responses (Chou et al., 1987). Furthermore, activation of the insulin receptor results in the tyrosine

Correspondence: PJ Coffer

Received 5 December 1996; revised 15 July 1997; accepted 16 July 1997 phosphorylation of several cellular proteins, most notably insulin-receptor substrate-1 (IRS-1) and the adaptor protein Shc (Sun et al., 1991; 1993; Skolnik et al., 1993; Pronk et al., 1993, 1994; Ouwens et al., 1994). Phosphorylated tyrosine residues provide unique binding sites for a subset of proteins containing modular Src homology-2 (SH2) domains (Pawson, 1995). Insulin-induced phosphorylation of IRS-1 results in binding and activation of phosphatidylinositol $3(\mathrm{OH})$-kinase (PI-3 $(\mathrm{OH})$ kinase), while phosphorylation of Shc results in the association of grb2-SOS complex (Pronk et al., 1994). This re-localization of the guanine-nucleotide exchange factor mSOS results in close contact with membrane-bound p21ras. The subsequent exchange of GDP for GTP on p21ras stimulates an intracellular signal transduction pathway involving several well-characterized cytoplasmic protein kinases that act to amplify the initial receptor-mediated signal (Burgering et al., 1993; Denton and Tavare, 1995).

Although knowledge has recently increased concerning the mechanisms by which insulin activates p21 ras and the immediate downstream signalling events, the activation of specific transcription factors and resultant gene induction remains relatively unknown. The activation of $\mathrm{p} 21$ ras signal transduction by a plethora of stimuli can lead to the phosphorylation of a number of transcription factors. These include: c-Jun (Binetruy et al., 1991; Pulverer et al., 1991), p62 ${ }^{\mathrm{TCF}} /$ Elk-1 (Marais et al., 1993), c-ets-1 (Coffer et al., 1993; Galang et al., 1994; Giovane et al., 1994), NF-IL6 (Nakajima et al., 1993), c-Fos (Deng and Karin, 1994) and c-Myc (Seth et al., 1992).

More recently a novel nuclear signalling pathway has been described that regulates a large family of transcription factors termed the STATs (Signal Transducers and Activators of Transcription; reviewed; Schindler and Darnell, 1995; Ihle, 1996a). This pathway was initally described for the interferon receptors (IFN- $\alpha$ and IFN- $\gamma$ ) but has subsequently been described for a large range of hemopoietic cytokines, growth factors and hormones. These transcription factors contain $\mathrm{SH}$-domains and are themselves tyrosine phosphorylated in response to cellular stimulation. This tyrosine phosphorylation of STATs provides both a nuclear localization signal and also allows dimerization critical for DNA-binding (Shuai et al., 1993, 1994). For receptors containing no intrinsic tyrosine kinase activity, the Janus kinase family (JAKs) appear to be responsible for the activating STAT-phosphorylation (Muller et al., 1993; Silvennoinen et al., 1993; Watling et al., 1993; 
Schindler and Darnell, 1995). However, for growthfactor receptors, which do contain an intrinsic kinase activity, such as the EGF and PDGF receptors, the STAT-phosphorylating activity has not been unequivocally determined (Shuai et al., 1993; Zhong et al., 1994; Coffer and Kruijer, 1995; Leaman et al., 1996; Vignais et al., 1996). Recent data has however indicated that both the EGF- and PDGF receptors are capable of activating STAT-transcriptional activity in the absence of JAK activation (Leaman et al., 1996; Vignais et al., 1996). Interestingly, several recent studies have proposed a role for p21ras-ERK signal transduction in modulating the JAK-STAT pathway through ERK phosphorylation of a conserved serineresidue necessary for STAT transactivation (reviewed: Ihle, 1996b).

Recently several studies have implicated activation of STAT transcription factors in the maintenance of the transformed state by various oncogenes. It has been shown that in leukemia cells and lymphoma celllines there is constitutive nuclear localisation, phosphorylation and DNA-binding activity of STAT proteins (Weber-Nordt et al., 1996). Furthermore, in chronic myelogenous leukemia (CML), cytokineindependent growth of leukemia cells correlates with constitutive Stat5 activation by the Bcr-Abl oncogene in CML patients (Danial et al., 1995; Carlesso et al., 1996; Shuai et al., 1996). These data have suggested a direct link between oncogenic transformation and cytokine signalling. Furthermore, cells stably transformed by the v-Src oncoprotein exhibited constitutive activation of Stat 3 and this activation correlated with Src transformation ( $\mathrm{Yu}$ et al., 1995). These findings raise the possibility that Stat3 also contributes to oncogenesis by Src.

To further address the mechanisms by which insulin can induce the expression of target genes we have utilized an NIH3T3 cell-line over-expressing the insulin receptor (A14 cells; Burgering et al., 1991). Stimulation of these cells with insulin results in a rapid and sustained phosphorylation of the insulin receptor, its major substrate IRS-1 and Shc. We have identified a DNA-binding complex induced by insulin that binds to a consensus STAT transcriptional element. This binding is inhibited by tyrosine- but not by serine/ threonine-kinase inhibitors. Supershift analysis reveals that insulin specifically activates Stat3 DNA-binding activity in both A14 cells and 3T3-L1 adipocytes. Furthermore, despite a potent activation of p21ras signal transduction in A14 cells by insulin, use of dominant-negative reagents demonstrated that this signalling pathway is not necessary for Stat3 activation. In contrast to recent reports (reviewed: Ihle, 1996b), insulin activation of Stat3 can occur in the absence of detectable MAP kinase or PI-3 kinase activity.

\section{Results}

Insulin stimulates DNA-binding and transactivation from STAT-transcriptional elements

To determine whether insulin was capable of activating members of the STAT-family of transcription factors, we utilized an NIH3T3 cell line stably transfected with the insulin receptor $\left(\mathrm{A} 14,3.0 \times 10^{5} /\right.$ cell; Burgering et al., 1991). These cells respond rapidly to insulin by receptor autophosphorylation, IRS-1 and Shc phosphorylation, p21ras activation and induction of downstream kinase cascades resulting in MAP kinase activation (Pronk et al., 1992, 1993; de Vries-Smits et al., 1992; Medema et al., 1993; Coffer et al., 1995a). To analyse the potential activation of STAT transcription factors we performed a gel retardation assay on insulin stimulated A14 cells. As a probe, a palindromic IL-6/ IFN- $\gamma$ response element (pIRE) from the ICAM-1 promoter was utilized. We have previously demonstrated that this consensus STAT-binding site is capable of binding both Statl and Stat3 and heterodimers thereof and is responsible for mediating the effects of IL- 6 and IFN- $\gamma$ on this promoter (Caldenhoven et al., 1994). A $\mathrm{A}^{32} \mathrm{P}$-labelled pIRE oligonucleotide was incubated with nuclear extracts from A14 cells treated for increasing periods of time with insulin. As shown in Figure la, no pIRE binding activity was observed in nuclear extracts isolated from untreated cells. Stimulation with insulin lead to a dramatic induction of a DNA-binding complex which was maximal at $15 \mathrm{~min}$, sustained for several hours and returned to basal levels within $20 \mathrm{~h}$ (Figure 1a). This long-term DNA-binding is in marked contrast to that observed on the same transcriptional element in HepG2 cells treated with IL-6 which returns to basal levels within an hour (Caldenhoven et al., 1994). Insulin treatment also results in rapid and long-term activation of the insulin receptor (INS-R) itself as measured by receptor tyrosine phosphorylation (Figure 1b).

To determine whether insulin is also capable of inducing transactivation from this STAT-binding element (pIRE), A14 cells were transiently transfected with thymidine kinase (tk) promoter constructs containing $1 \times$ or $2 \times$ copies of the pIRE. While the control empty vector (without pIRE enhancer) was not inducible by insulin, activity of the $1 \times$ IRE and $2 \times$ IRE constructs was clearly induced (Figure 1c). Taken together, these results suggest that insulin is indeed capable of inducing both DNA-binding activity and transactivation of a STAT-binding transcriptional element. To further analyse whether pIRE activation was specific we examined the dose-response. Indeed, increasing amounts of insulin resulted in a corresponding increase in pIRE-mediated CAT production (Figure 1d).

To define binding specificity of the insulin-induced binding complex, competition experiments were performed in a gel-retardation experiment (Figure 2). Addition of excess unlabelled pIRE probe completely inhibited the formation of the insulin-induced complex. As a control, competition was performed with a mutant pIRE that can no longer bind STAT-family members (mIRE; Caldenhoven et al., 1994). This oligonucleotide had no effect on induced binding activity. Furthermore, in order to determine whether the insulin-induced complex was able to bind other STAT-binding elements from other promoters, we utilized oligonucleotides designed from both the $\alpha_{2}$ macroglobulin promoter and the c-fos promoter The cfos gene is rapidly induced by insulin in a variety of cell-types (Campos and Baumann, 1992; Medema al., 1992; Heindenrich et al., 1993; Olson and Pessin; 1994; 
a

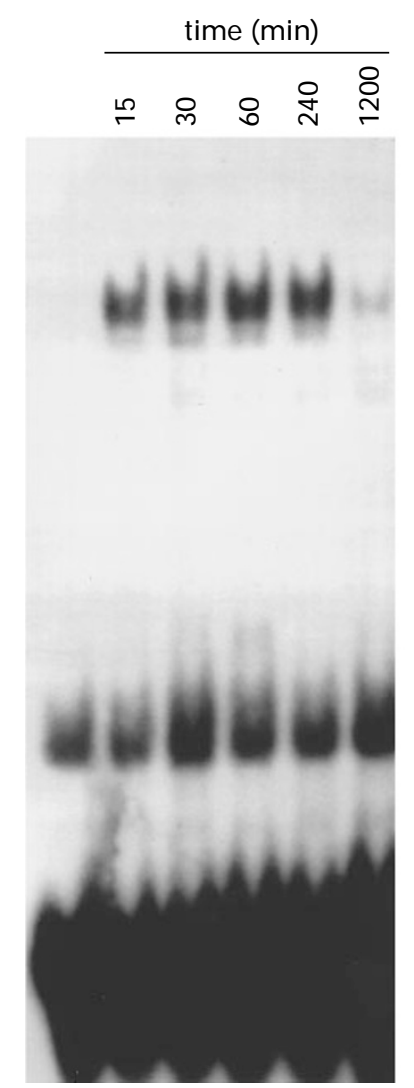

b

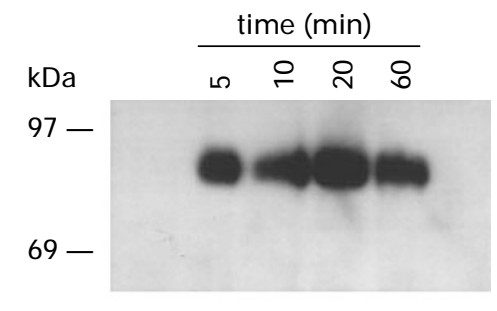

c

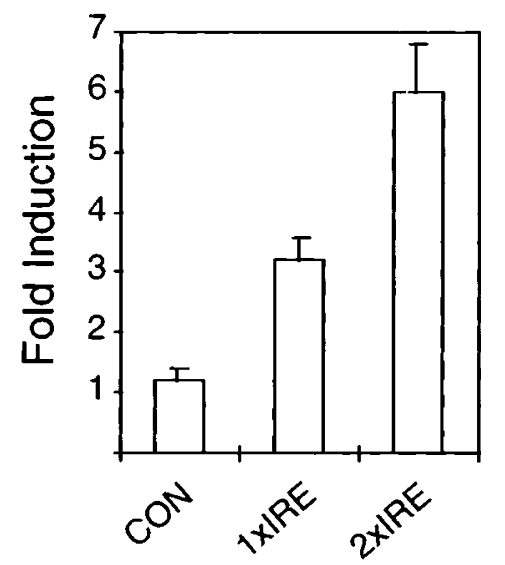

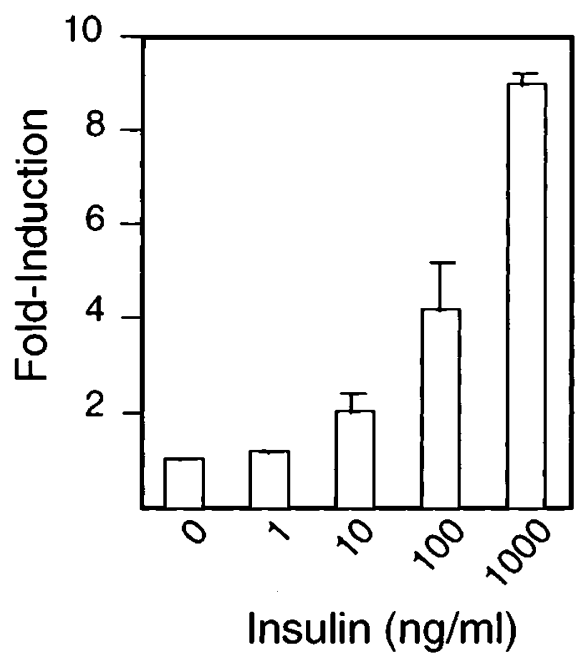

Figure 1 Insulin activates a pIRE binding activity. (a) A14 cells were either treated or untreated with insulin (1 $\mu \mathrm{g} / \mathrm{ml})$ for the indicated times and nuclear extracts isolated. $5 \mu \mathrm{g}$ of nuclear extract was mixed with double-stranded ${ }^{32} \mathrm{P}-\mathrm{labelled}$ ICAM-1 pIRE oligonucleotide and analysed by a gel retardation assay as described under Materials and methods. The arrow indicates a specific insulin-inducible pIRE-binding complex. (b) A14 cells were either untreated or treated with insulin (1 $\mu \mathrm{g} / \mathrm{ml})$ for the indicated times and the insulin receptor- $\beta$ was immunoprecipitated. Samples were separated by $10 \%$ SDS - PAGE, transferred to membrane and probed with anti-phosphotyrosine monoclonal antisera (PY-20). (c) A14 cells were transfected with $6 \mu \mathrm{g}$ of either tkCAT, $1 \times$ IRE-tkCAT or $2 \times$ IRE-tkCAT reporter construct together with $4 \mu \mathrm{g} \mathrm{pSV}$-lacZ as an internal control for transfection efficiency. Transfected cells were stimulated with insulin $(1 \mu \mathrm{g} / \mathrm{ml})$ for $16 \mathrm{~h}$. CAT assays were performed on samples corrected for $\beta$-galactosidase activity. Data represents the mean of three independent experiments \pm s.e.m. (d) A14 cells were transiently transfected with $2 \times$ IRE-tkCAT reporter construct. Cells were stimulated for $16 \mathrm{~h}$ with insulin at the indicated concentrations. CAT assays were performed on samples corrected for $\beta$-galactosidase activity. Data represents the mean of three independent experiments \pm s.e.m.

Jhun et al., 1995) and the $\alpha_{2}$-macroglobulin promoter has been demonstrated to contain a potent STATbinding site (Horn et al., 1994; Yuan et al., 1994). As can be seen in Figure 2, these STAT-binding elements are both able to potently compete, and therefore bind, the insulin-induced DNA-complex. This observation may indeed provide a mechanism by which insulin can rapidly induce c-fos expression in responsive cells.

\section{Insulin specifically activates Stat3}

As mentioned, we have previously demonstrated that the pIRE is capable of binding both Stat1, Stat 3 and heterodimers thereof (Caldenhoven et al., 1994). To resolve which STAT transcription factor is responsible for the DNA-binding activity observed after insulin stimulation, we performed supershift analysis of pIRE binding complexes (Figure 3a). Nuclear extracts were prepared from insulin-treated A14 cells, IFN- $\gamma$-treated HepG2 cells and EGF-treated A431 cells. These extracts were pre-incubated with antisera specific for either Stat $1 \alpha$ or Stat3. Results clearly demonstrate that in A14 cells the Stat3-specific antibody effectively

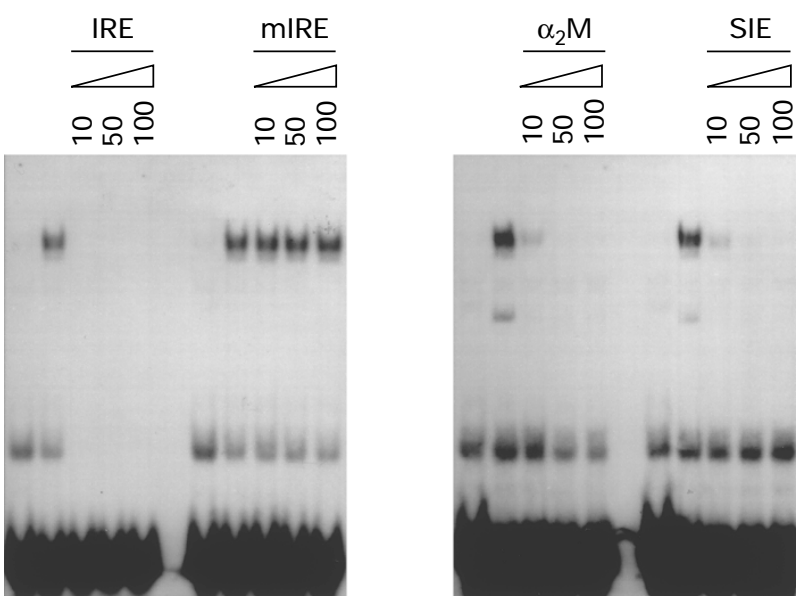

Figure 2 Insulin-induced complex binds STAT-binding sites specifically. A14 cells were either treated or untreated with insulin $(1 \mu \mathrm{g} / \mathrm{ml})$ for $15 \mathrm{~min}$. $5 \mu \mathrm{g}$ of nuclear extracts were incubated either in the absence or presence of $10 \times, 50 \times$ or $100 \times$ molar excess of competitor oligonucleotide as indicated before being mixed with double-stranded ${ }^{32} \mathrm{P}$-labelled ICAM-1 pIRE oligonucleotide and analysed by a gel retardation assay as described under Materials and methods 
supershifted the pIRE-binding complex induced by insulin (Figure 3a). In contrast an antibody specific to Stat $1 \alpha$ did not react with the insulin-induced complex. In HepG 2 cells, the same pIRE oligonucleotide probe is capable of strongly binding IFN- $\gamma$ induced Stat $1 \alpha$ as demonstrated by supershift analysis (Figure 3a), while in A431 cells the pIRE element is demonstrated to bind both Stat1, Stat 3 and heterodimeric complexes. Finally, to determine if in A14 cells it was indeed possible to activate a Stat1 DNA-binding activity, we treated these cells with IFN- $\alpha$ as indicated (Figure $3 b$ ). Here we see that the insulin-induced complex migrates with the IFN- $\alpha$ induced Stat 3 complex (complex-A). However, in contrast to insulin in A14 cells, IFN- $\alpha$ is also capable of inducing Stat 1 and heterodimeric complexes binding to the pIRE probe (complex-B, complex-C). This STAT-induction pattern is reminiscent of that observed with EGF in A431 cells (Figure 3a). Thus A14 cells do not lack functional Statl $\alpha$. These data clearly demonstrate that insulin is only capable of activating Stat3 in A14 cells which is in marked contrast to IFN- $\alpha$. Furthermore, we and others have previously demonstrated that in NIH3T3 cells stably transfected with the EGF receptor (Her14 cells), challenge with EGF results in a potent and rapid activation of Stat1, Stat3 and heterodimers thereof (Silvennoinen et al., 1993; Coffer and Kruijer, 1995). Together these data demonstrate that insulin appears to specifically target Stat3 and is incapable of activating Stat1.

To determine if insulin was capable of activating STAT DNA-binding in cells expressing endogenous insulin receptor we utilised 3T3-L1 adipocytes. Nuclear extracts were prepared from untreated and insulin treated adipocytes and bandshift analysis performed (Figure 3c). As a control, CNTF-treated P19 EC cell nuclear extract was prepared (known to stimulate Stat3 DNA-binding; PC and AvP submitted). It can be clearly seen that insulin stimulates STAT DNA-binding activity in 3T3-L1 adipocytes and that this co-migrates with the Stat3 complex induced by CNTF in P19 EC cells. Furthermore, preincubation of the nuclear extract with Stat3 specific antisera resulted in supershift of the binding complex demonstrating that in these cells Stat3 is also activated.

\section{Insulin-induced DNA-binding activity requires tyrosine but not serine kinase activity and is independent of p21ras}

The binding of insulin to its receptor elicits a variety of cellular responses and a variety of protein kinase activities have been implicated in insulin-induced signal transduction. We wished to analyse how these protein kinase activities may regulate transcriptional induction by insulin-induced Stat3. We and others have demonstrated that Stat 3 undergoes both tyrosine and serine phosphorylation in response to several stimuli (Boulton et al., 1995; Lutticken et al., 1995; Wen et al., 1995; Zhang et al., 1995). To determine if insulin-induced Stat3 activation is regulated in a similar fashion we first pre-treated A14 cells with genestein, a tyrosine kinase inhibitor, or $\mathrm{H} 7$ a serine/ threonine kinase inhibitor, and then stimulated them with insulin. As can be seen from Figure 4a, increasing amounts of genestein potently inhibit insulin-induced Stat3 DNA-binding activity, while relatively high concentrations of $\mathrm{H} 7$ have no effect. The lack of effect of $\mathrm{H} 7$ on insulin-induced Stat3 DNA-binding is in contrast to that observed by Zhang et al., (1995) where H7 was shown to inhibit the formation of interferon-induced DNA-complexes by Stat 3 homodimers. However, this effect has not been widely observed and appears to be both sequence-specific and cell-type specific (Coffer et al., 1995b; Lutticken et al., 1995; Boulton et al., 1995).

Although hemopoietic cytokine receptors appear to require JAK tyrosine kinase activity for STAT DNAbinding activity (Muller et al., 1993; Watling et al., 1993) recent data has suggested that for growth-factor receptors this is not the case (Leamann et al., 1996; Vignais et al., 1996). These studies have demonstrated that either the intrinsic kinase activity of these receptors or an undefined downstream tyrosine kinase is involved. To determine whether p21ras may be involved in activation of Stat3 DNA-binding, we utilized a recombinant vaccinia virus expressing an interfering mutant of p21ras, p21 ras $^{\mathrm{Asn}-17}$. Previously we have demonstrated that in A14 cells this recombinant virus inhibits insulin-induced activation of ERK2 completely, but there is no inhibition of insulin-induced phosphatidylinositol-3(OH) kinase activity (de Vries-Smits et al., 1992). A14 cells were infected with wild-type vaccinia virus (vv-wt) and vv$\operatorname{Ras}^{\mathrm{Asn}-17}$ and after $16 \mathrm{~h}$ stimulated for the indicated times with insulin. Nuclear extracts were prepared and gel-retardation analysis performed (Figure 4b). As can be seen there is no effect of p21 ras Asn-17 expression on the insulin-induced DNA-binding activity of Stat3. This is in agreement with the results of Silvennoinen et al. (1993) who demonstrated that dominantnegative p21ras did not inhibit STAT DNA-binding in response to PDGF. As a control, total cell-lysates were prepared in parallel and analysed by anti-ERK2 western blotting for activation of MAP kinase phosphorylation (Figure 4c). Expression of p21 ras ${ }^{\text {Asn-17 }}$ completely inhibits the insulin-induced activation of ERK2 phosphorylation. These data demonstrate a role for tyrosine kinase but not serine kinase activity in insulin-induced Stat3 DNA-binding independently of p21ras activation.

\section{Insulin-induced Stat3 transactivation is independent of p21ras, MAP kinase or PI-3(OH) kinase activation}

We and others have recently reported a role for serinephosphorylation in mediating the transactivation potential of STAT transcriptional factors and it has been suggested that this phosphorylation could be mediated by the ERK1/ERK2 MAP kinases (Boulton et al., 1995; Lutticken et al., 1995; Wen et al., 1995; Zhang et al., 1995; David et al., 1995). Previous data has demonstrated that p21ras was not involved in STAT DNA-binding, a tyrosine-kinase dependent process (Silvennoinen et al., 1993). However, these studies did not address the question of transactivation, an independent process, as previously mentioned, involving serine-phosphorylation (reviewed: Ihle, 1996b). To investigate whether there was a role for p21ras-ERK signal transduction in the case of insulinstimulated Stat3 transactivation, we analysed the 
effects of dominant-negative expression constructs and protein kinase inhibitors on insulin-mediated Stat3 transactivation (Figure 5). A14 cells were transiently transfected with either a pIRE CAT-reporter construct or an SRE CAT-reporter (Coffer et al., 1995a). Stimulation of cells with insulin resulted in an induction of CAT-activity for both reporter constructs (IRE, tenfold; SRE, fivefold). The addition of p21 ras ${ }^{\mathrm{Asn}-17}$ results in only a minor reduction of IREmediated CAT-activity, compared to an almost complete inhibition of insulin-stimulated SRE CATactivity. Use of an interfering-mutant of c-raf (N $\Delta$ Raf) gave essentially the same results (data not shown). We utilized several protein kinase inhibitors: H7, previously shown to inhibit Stat3 transactivation (Boulton et al., 1995; Lutticken et al., 1995); wortmannin, a potent phosphatidylinositol-3(OH) kinase (PI-3(OH) kinase) inhibitor (Wymann et al., 1996); and PD098059 a recently described specific MEK inhibitor shown to inhibit the activation of MAP

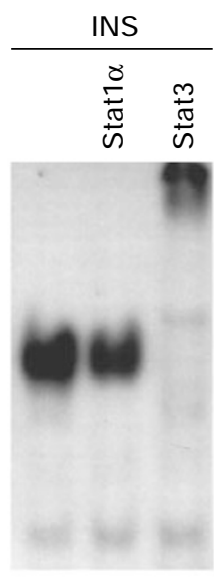

A14

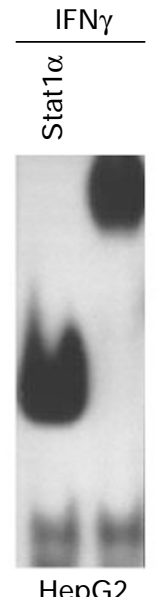

HepG2

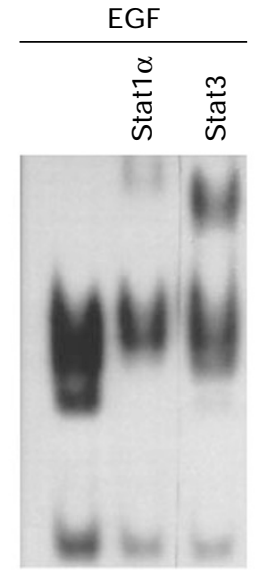

A431 b

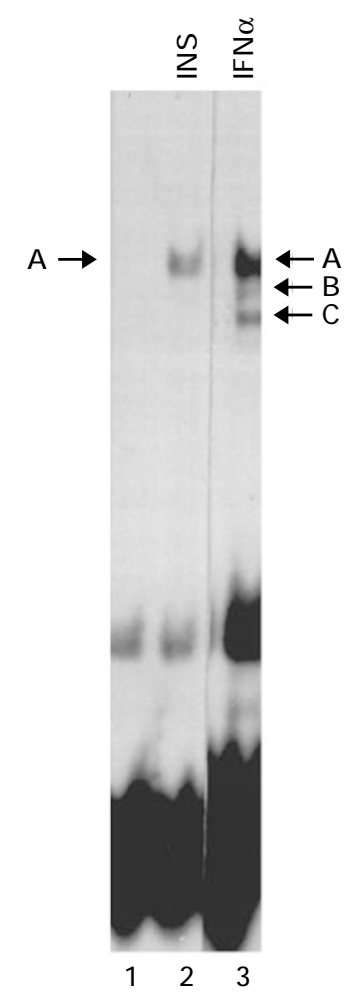

c

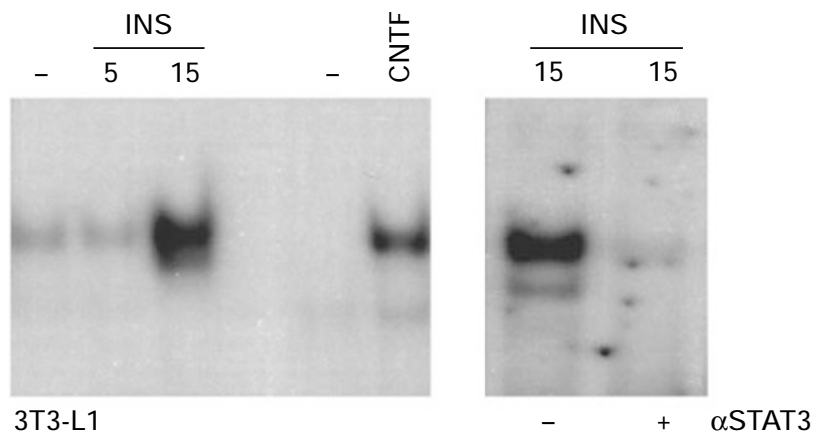

Figure 3 Insulin specifically activates Stat3. (a) Supershift analysis of insulin-induced ICAM-1 pIRE binding activity. Nuclear extracts were prepared from A14 cells treated with insulin $(1 \mu \mathrm{g} / \mathrm{ml})$, HepG2 cells treated with IFN- $\gamma(100 \mathrm{U} / \mathrm{ml})$ and A431 cells treated with EGF $(50 \mathrm{ng} / \mathrm{ml})$ for $15 \mathrm{~min}$. The extracts were incubated with either anti-Stat $1 \alpha$ or anti-Stat 3 specific antibodies for 30 min before addition of ${ }^{32}$ P-labelled pIRE. (b) IFN- $\alpha$ activates Stat 1 and Stat3 in A14 cells. A14 cells were treated with insulin $(100 \mathrm{ng} / \mathrm{ml})$ or IFN- $\alpha(500 \mathrm{U} / \mathrm{ml})$ and analysed for pIRE binding by gel-retardation analysis. (c) Insulin activates Stat3 in 3T3-L1 adipocytes. Nuclear extracts were prepared from 3T3-L1 adipocytes treated with insulin $(1 \mu \mathrm{g} / \mathrm{ml})$ or P19 EC cells treated with CNTF for $15 \mathrm{~min}$ and analysed by gel. For supershift analysis extract was pre-incubated anti-Stat3 specific antibody for 30 min 


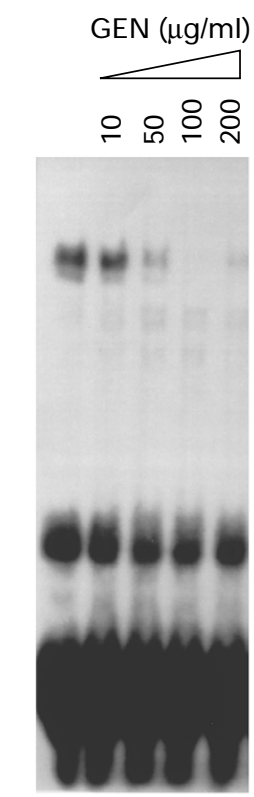

$\mathrm{H} 7(\mu \mathrm{M})$

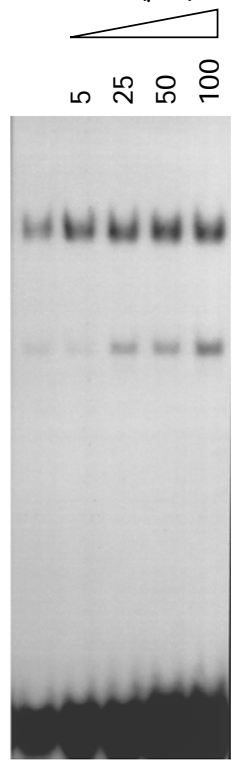

c

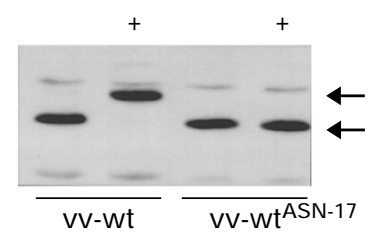

510

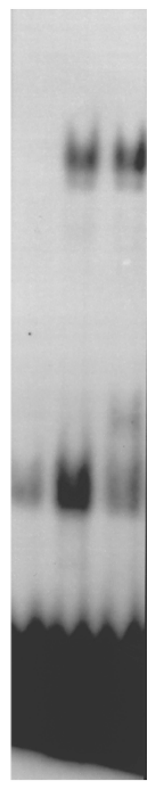

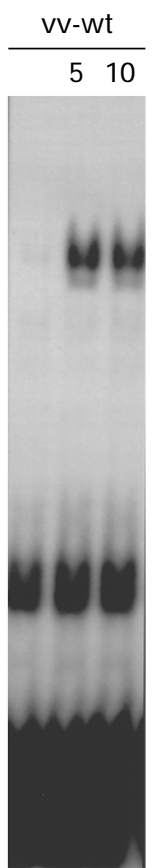

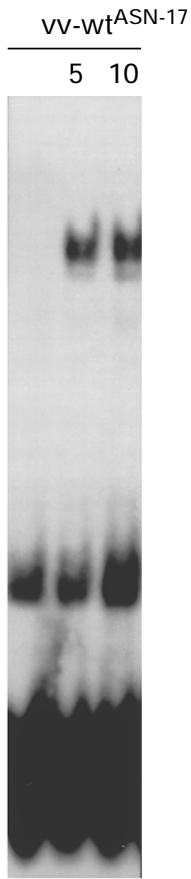

Figure 4 Insulin-mediated activation of Stat3 DNA-binding is dependent on tyrosine kinase activity and independent of p21 ras. (a) Insulin stimulated pIRE-binding is inhibited by pre-treatment with genestein but not H7. A14 cells were pre-incubated for 20 min with protein kinase inhibitors at the concentrations indicated. Cells were then stimulated with insulin (1 $\mu \mathrm{g} / \mathrm{ml})$ for $15 \mathrm{~min}$ and nuclear extracts prepared. Binding reactions were with $5 \mu \mathrm{g}$ nuclear protein extract and ${ }^{32} \mathrm{P}$-labelled pIRE. The position of the insulin-induced Stat 3 complex is marked with an arrow. (b) Insulin-mediated activation of Stat3 is dependent of p21ras. A14 cells were infected with wild-type vaccinia virus or virus expressing p21 ras ${ }^{\text {Asn-17 }}$ as described in Materials and methods. Nuclear extracts were then prepared from insulin-treated cells at the times indicated and analysed by gel-retardation assay. (c) Insulin-mediated MAP kinase activation is inhibited by 21 ras $^{\text {Asn-17. }}$. A14 cells were infected as above and treated with or without insulin for 5 min. Samples were analysed for ERK2 phosphorylation by SDS-PAGE and $\alpha$ ERK immunoblotting. Arrows indicated the position of ERK2

kinase (Allessi et al., 1995; Dudley et al., 1995). Addition of $50 \mu \mathrm{M} \mathrm{H} 7$ results in a potent inhibition of IRE-mediated CAT-activity while the use of $100 \mathrm{nM}$ wortmannin, sufficient to inhibit PI-3 kinase (data not shown), results in no effect on IRE-mediated CAT activity (Figure 5a). Finally, the use of PD098059 results in only a very minor reduction of IRE-mediated CAT-activity.

To determine the effect of these kinase inhibitors on activation of MAP kinases by insulin, we analysed both insulin-mediated phosphorylation of ERK2 (Figure 5b) and also insulin-induced activity of ERK1 (Figure 5c). As can be clearly seen in Figure 5 b, insulin stimulates a complete shift of ERK2 in A14 cells. Pre-treatment of cells with either wortmannin or $\mathrm{H} 7$ does not result in a decrease in this phosphorylation/shift. However, pre-treatment of A14 cells with PD098059 completely inhibits insulin-stimulated ERK2 phosphorylation. Furthermore, we analysed the insulin-stimulated ERK1 activity in A14 cells with and without pre-treatment with PD098059 (Figure 5c). Cells were transiently transfected with an epitopetagged ERK1 construct (Burgering and Coffer, 1995) and after insulin-treatment HA-ERK1 was immunoprecipitated and MBP-phosphorylating activty determined. Insulin stimulates a dramatic increase in ERK1 activity and this is completely inhibited by preincubation with PD098059. Pre-treatment with H7 resulted in no detectable decrease in ERK1 MBPphosphorylating activity (data not shown).

Taken together these data suggest that IRE-activity is inhibited under conditions that do not inhibit MAP kinase activation and conversely conditions that inhibit MAP kinase activation do not inhibit Stat3-transactivation. This result is in contrast to the recent report of David et al. (1995) which demonstrated a role for MAP kinase in IFN $\alpha / \beta$ stimulated Stat1 activation.

We and others have reported that activation of Stat3 results in serine phosphorylation causing a reduction in migration during polyacrylamide gel electrophoresis (Boulton et al., 1995; Lutticken et al., 1995; Ceresa and Pessin, 1996). To determine if insulin stimulated Stat3 phosphorylation was inhibited by pre-incubation with H7, PD098059 or wortmannin, A14 cells were transfected with a Stat3 expression construct. After pre-incubation with inhibitors, cells were stimulated 


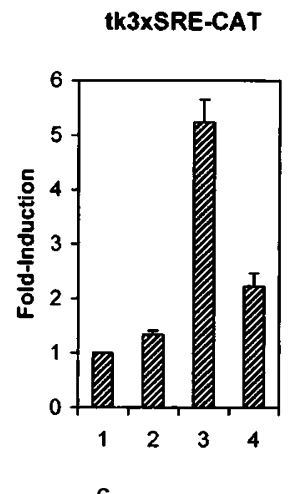

b
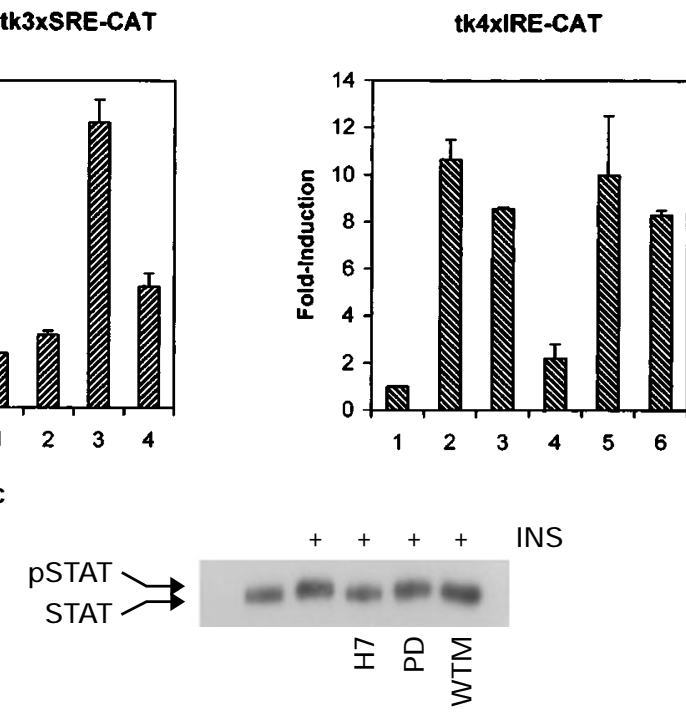
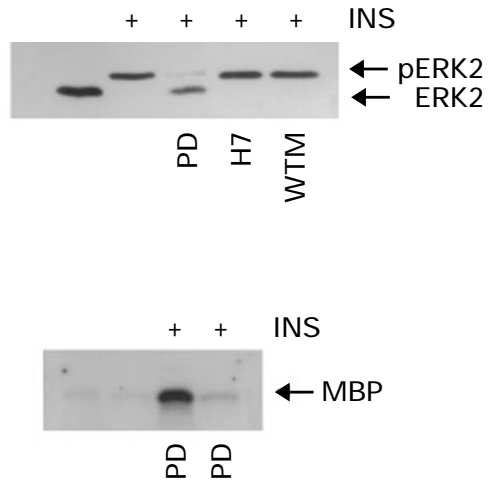

Figure 5 Insulin stimulates Stat 3 transactivation independently of p21ras-ERK or PI-3(OH) kinase signal transduction. (a) Insulinmediated STAT-transactivation is inhibited by H7 but not by p21ras ${ }^{\text {Asn17, }}$, wortmannin or PD098059 (Mek inhibitor). A14 cells were transfected with either $4 \mu \mathrm{g}$ of tk $3 \times \mathrm{SRE}$-CAT or tk $4 \times$ IRE-CAT reporter construct together with $4 \mu \mathrm{g}$ pSV $\mathrm{I}_{2}$-lacZ as an internal control for transfection efficiency. Pre-treatment with inhibitors was for $20 \mathrm{~min}$. Transfected cells were stimulated with insulin $(1 \mu \mathrm{g} /$ $\mathrm{ml}$ ) for $6-8 \mathrm{~h}$ and CAT assays were performed on samples corrected for $\beta$-galactosidase activity. Data represents the mean of three independent experiments \pm s.e.m. Left panel: 1 , unstimulated; $2,2 \mu \mathrm{g}$ p21 $\mathrm{ras}^{\text {Asn } 17} ; 3-4$, insulin $(1 \mu \mathrm{g} / \mathrm{ml})$ and $4,2 \mu \mathrm{g}$ p21ras ${ }^{\text {Asn } 17}$. Right panel: 1, unstimulated; 2-6, insulin $(1 \mu \mathrm{g} / \mathrm{ml}) ; 3,50 \mu \mathrm{M}$ PD098059; 4, $50 \mu \mathrm{M} \mathrm{H} 7 ; 5,100 \mathrm{nM}$ wortmannin; 6, $2 \mu \mathrm{g}$ p21ras Asn17. (b) Insulin-mediated MAP-kinase activation is inhibited by PD098059 but not by H7 or wortmannin. A14 cells were pre-incubated for $20 \mathrm{~min}$ with or without inhibitors as indicated. Cells were then stimulated for $5 \mathrm{~min}$ with insulin $(1 \mu \mathrm{g} / \mathrm{ml}), \mathrm{lysed}$ in sample buffer and analysed by SDS-PAGE with anti-ERK western blotting. The position of the phosphorylated form of ERK2 is marked by an arrow. For kinase assays, A14 cells were pre-treated for $20 \mathrm{~min}$ with or without MEK-inhibitor and then stimulated for 5 min with insulin $(1 \mu \mathrm{g} / \mathrm{ml})$. HA-ERK1 was immunoprecipitated as described in Materials and methods and MBP-phosphorylating activity analysed. (c) Insulin stimulated STAT3 phosphorylation is inhibited by H7 but not PD098059 or wortmannin. A14 cells were transfected with $4 \mu \mathrm{g}$ pSG5-Stat3. Sixteen hours before stimulation media was refreshed to DMEM $+0.5 \%$ FCS. Inhibitors H7 $(50 \mu \mathrm{M})$, PD098059 $(50 \mu \mathrm{m})$ and wortmannin $(100 \mathrm{nM})$ were pre-incubated for $30 \mathrm{~min}$. After addition of insulin (1 $\mu \mathrm{g} / \mathrm{ml})$ for 15 min, Stat 3 was specifically immunoprecipitated and analysed by $10 \%$ SDS-PAGE and anti-Stat3 Western blotting. The position of unphosphorylated and phophorylated Stat 3 is marked with an arrow

with insulin for $15 \mathrm{~min}$ before lysis and Stat3 immunoprecipitation. Samples were resolved by $10 \%$ SDS-PAGE and analysed by anti-Stat3 western blotting. As can be seen in Figure 5c, insulintreatment results in an upshift in Stat3. Pre-treatment of A14 cells with $\mathrm{H} 7$, previously demonstrated to inhibit serine-phosphorlation of Stat3 (Boulton et al., 1995; Lutticken et al., 1995) indeed inhibited the Stat3upshift. However, treatment with PD098059 or wortmannin failed to reduce Stat 3 migration supporting the conclusions reached that neither p21ras-ERK or PI-3K signalling influences the transactivation or serine-phosphorylation of Stat3.

\section{Discussion}

The recent cloning of the STAT transcription factors has resulted in their identification as playing a prominent role in stimulus-mediated gene expression (Schindler and Darnell, 1995; Ihle, 1996a). Furthermore, studies have implicated constitutive activation of STATs in transformed cells with the maintenance of the oncogenic phenotype (Daniel et al., 1995; Yu et al., 1995; Carlesso et al., 1996; Weber-Nordt et al., 1996; Shuai et al., 1996). The evolutionary significance of STATs has only become clear with the recent identification and characterization of conserved Drosophilia STAT-homologues (Ihle, 1996a, Hou et al., 1996;
Yan et al., 1996). Initial work with the interferon receptors (IFN- $\alpha$, IFN- $\beta$, IFN- $\gamma$ ) demonstrated a critical role for the JAK tyrosine kinases in mediating STAT activation by hemopoietic cytokine receptors that contain no intrinsic tyrosine kinase activity (Muller et al., 1993; Silvennoinen et al., 1993; Watling et al., 1993). However, more recent work with the EGF- and PDGF receptors has shown that other receptor families are capable of stimulating STAT transcription factors and that this activation appears to be independent of JAK kinase-activity (Leaman et al., 1996; Vignais et al., 1996). The EGFR itself, for example, contains phosphorylated tyrosine residues in a local sequence environment that could potentially mediate STAT SH2-phosphotyrosine interactions, although no direct association in vivo has yet been shown (Silvennoinen et al., 1993; Coffer and Kruijer, 1995). This observation suggests that for receptors with intrinsic tyrosine kinase activity, autophosphorylated tyrosine residues may provide docking-sites that bring STATs to the membrane where they can then be phosphorylated by the receptor kinase itself. The insulin receptor however, is somewhat different from the EGFR, as its major substrate IRS-1 tends to provide the phosphotyrosine residues necessary for docking of SH2-containing proteins rather than the autophosphorylated receptor itself (Sun et al., 1991, 1993; Skolnik et al., 1993). The phosphorylation of IRS-1 upon tyrosine residues results in interactions 
with PI-3(OH) kinase, SHPTP-2 and GRB2. However, neither the autophosphorylated sites in the insulin receptor itself, or the tyrosine phosphorylated residues in IRS-1, conform to the Stat3 binding-motif YXXQ recently described, or Stat 1 binding motifs identified in the IFN- $\gamma$ receptor (Greenlund et al., 1995; Schindler et al., 1995; Stahl et al., 1995). Thus it is at the moment unclear as to how the insulin-induced Stat3 is being brought to the membrane for activation.

The treatment of A14 cells with insulin results in only Stat 3 activation, even with very high insulin concentrations $(1 \mu \mathrm{g} / \mathrm{ml})$. This is in direct contrast to that observed with IFN- $\alpha$ in the same cells which is able to activate Stat1, Stat3 and heterodimers thereof (Figure 3b). Interestingly NIH3T3 cells stably transfected with the EGFR (Her14) are also able to strongly activate Stat1, Stat3 and heterodimers thereof (Silvennoinen et al., 1993; Coffer and Kruijer, 1995). This indicates that there are significant differences between these two tyrosine kinase receptors in the same cell-type. As mentioned, this may be accounted for by the phosphotyrosine docking-sites provided by both receptors, or otherwise by an inability for the insulinstimulated tyrosine kinase to phosphorylate Stat $1 \alpha$. While the EGFR tyrosine kinase appears to be able to directly phosphorylate and activate Stat1 (Quelle et al., 1995), this has not been determined for the insulin receptor.

The insulin-induced Stat 3 complex was able to bind the SIE transcriptional element from the c-fos promoter as demonstrated by competition studies (Figure 2). Transgenic mouse studies have implicated this transcriptional element as a mediator of c-fos expression in vivo (Robertson et al., 1995). Recently, Hill and Treisman (1996) have reported that in NIH3T3 cells, CSF-1, PDGF and EGF activate the c-fos promoter via co-operation of the SIE and SRE. However, activation by the SRE is context-dependent such that interferons can activate STAT DNA-binding activity and transcription of SIE reporter genes, but not the c-fos promoter which requires additional p21ras-dependent signals. Insulin-mediated SRE-activation is inhibited by $\mathrm{p} 21 \mathrm{ras}^{\mathrm{Asn}-17}$ while IRE-induction is not (Figure 5a). Thus, insulin activation of c-fos expression could also be envisaged to occur via synergistic interaction of Stat3 SIE-binding and p21ras-mediated SRF/TCF-binding.

During the preparation of this manuscript, an article concerning insulin-induced serine phosphorylation of Stat3 was published (Ceresa and Pessin, 1996). This study utilised both $\mathrm{CHO}$ cells expressing the human insulin receptor and differentiated 3T3L1 adipocytes. In agreement with our study, the authors show that Stat3 is the only target of insulin-induced STATactivation. However, Ceresa and Pessin analyse only an electrophoretic mobility shift of STATs by Western blotting in response to insulin and do not analyse the functional significance of this with respect to DNAbinding or transactivation (Ceresa and Pessin, 1996). In this paper we demonstrate by gel-retardation and supershift analysis that insulin only induces Stat3 DNA-binding (Figure 3) and results in transactivation of reporter constructs (Figure 2).

Recently an interesting possibility has arisen that the p21ras-pathway may interact with the JAK-STAT pathway at the level of MAP kinase (reviewed: Ihle, 1996b). Although previous studies have addressed the role of p21ras in STAT DNA-binding, the question as to a potential transactivation function was not investigated (Silvennoinen et al., 1993). We and others have previously demonstrated that Stat3 is serine phosphorylated by an H7-sensitive kinase and that this phosphorylation is necessary for transactivation (Boulton et al., 1995; Lutticken et al., 1995). Furthermore, Wen et al. (1995) demonstrated that Stat $1 \alpha$ is serine-phosphorylated at a site conserved in Stat3 (Ser-727) and that this site could also potentially be phosphorylated by MAP kinase. Most recently, a report showed that interferons not only activate MAP kinase activity, but there is an in vivo association between Stat1 and ERK2 (David et al. 1995). Utilising dominant-negative ERK2 it was demonstrated that transcriptional activation of an ISRE reporter construct is reduced by $60 \%$. Our data is in marked contrast to that of David et al., (1995). In A14 cells, MAP kinase activation is dependent on p21ras. Thus, co-transfection of $\mathrm{p} 21 \mathrm{ras}^{\mathrm{Asn}-17}$ inhibits SRE induction in these cells, as this appears to be MAP kinase-dependent while there is no effect on IRE induction (Figure 5). Furthermore, utilising the specific MEK inhibitor (PD098059) we demonstrate that although both ERK1 and ERK2 activity is abolished, insulin-induced IREactivity is still present. Finally, $\mathrm{H} 7$ which is a potent inhibitor of Stat3 transactivation (Boulton et al., 1995; Lutticken et al., 1995), does not effect MAP kinase activation in A14 cells (Figure 5). Taken together, these data demonstrate that insulin-induction of Stat 3 activity in NIH3T3 cells is independent of p21ras-ERK signalling, and also appears to be independent of PI$3(\mathrm{OH})$ kinase activity as shown by the lack of effect of high concentrations of wortmannin, a potent PI-3(OH) kinase inhibitor (Figure 5). A very recent report has implicated PI-3K as a mediator of Stat3 activation (Pfeffer et al., 1997). The p85 regulatory subunit of PI$3 \mathrm{~K}$ was found bound to Stat3 in association with interferon- $\alpha$ receptor and underwent interferon stimulated tyrosine phosphoryation. In contrast to our data (Figure 5), Pfeffer et al. demonstrate that incubation of cells with wortmannin does inhibit interferon- $\alpha$ induced Stat 3 phosphorylation, as measured by gel-shift. These data suggest that in contrast to our data with insulin, interferon- $\alpha$ stimulated Stat3 serine-phosphorylation may be mediated by a PI-3K dependent pathway. Thus the signalling pathways utilised in stimulation of STAT-transactivation potential are likely to involve both receptor-specific and cell-type specific downstream events.

The question arises as to which kinase may be responsible for the transactivating phosphorylation of Stat3? Potential candidates could include the JNK/ SAPKs which not only activate Jun transactivation but also ATF-2 and ETS-family members (Derijard et al., 1994; Kyriakis et al., 1994; Minden et al., 1994; Sanchez et al., 1994; Su et al., 1994; Gupta et al., 1995). These protein kinases could potentially phosphorylate the Pro-Met-Ser-Pro motif in Stat3 and may be activated by many of the stimuli that can activate this transcription factor. Indeed, it has recently been reported that insulin can activate JNK/SAPKs (Miller et al., 1996). Further experiments will no doubt identify the potential roles of MAP kinase and other 'Ser-Pro'directed kinases in STAT transactivation. 


\section{Materials and methods}

Cell culture, reagents and antibodies

A14 cells have been previously described (Burgering et al., 1991) and were cultured in Dulbecco's modified Eagle's medium (DMEM) supplemented with 10\% heat-inactivated fetal calf serum (FCS). Prior to stimulation cells were cultured for $16 \mathrm{~h}$ in DMEM supplemented with $0.5 \%$ FCS. Insulin receptor- $\beta$, Stat $1 \alpha$ and Stat 3 antibodies were purchased from Santa Cruz Biotechnology Inc., Santa Cruz; anti-phosphotyrosine antibody (PY20) was purchased from Transduction Labs, Kentucky. Wortmannin, genestein, PD098059 and H7 were purchased from BioMol Research laboratories Inc., PA. ERK2 and 12CA5 antisera have been previously described (de Vries-Smits et al., 1992; Burgering and Coffer, 1995).

\section{Insulin receptor tyrosine phosphorylation}

After stimulation with insulin, cells were lysed in $2 \mathrm{~mm}$ Tris-Cl $\mathrm{pH} 7.4,150 \mathrm{~mm} \mathrm{NaCl}, 0.5 \%$ Triton X-100, $0.1 \%$ SDS, $1 \mathrm{~mm}$ EDTA, 1mM PMSF, $100 \mathrm{~mm}$ NaF, $0.1 \mu \mathrm{M}$ aprotinin and $1 \mathrm{mM}$ sodium orthovanadate. Lysates were cleared by centrifugation at $4{ }^{\circ} \mathrm{C}$ for $10 \mathrm{~min}$ at $14000 \mathrm{~g}$. Cleared lysates were then incubated with the appropriate antibodies on a rotating wheel at $4{ }^{\circ} \mathrm{C}$ for $2 \mathrm{~h}$. After this time Protein-A sepharose was added to the samples at $4^{\circ} \mathrm{C}$ for a further $1 \mathrm{~h}$. Precipitates were washed three times with lysis buffer, resuspended in Laemmli buffer and heated for $5 \mathrm{~min}$ at $95^{\circ} \mathrm{C}$ before running on a $12.5 \%$ SDSpolyacrylamide gel. Proteins were transferred to Immobilon-P (Amersham) and immunoblotted with PY20 antisera according to standard protocols. Blots were developed utilising Enhanced Chemiluminescence (ECL, Amersham).

\section{Stat 3 and ERK2 phosphorylation}

Cells were cultured as described above and stimulated with insulin. After treatment, cells were washed twice in ice-cold PBS and either immediately lysed in sample buffer (ERK2) or immunoprecipitated with anti-Stat3 sera. After being heated for $5 \mathrm{~min}$ at $95^{\circ} \mathrm{C}$, total cell-lysates were run out on $10 \%$ SDS-polyacrylamide gels. Proteins were transferred to Immobilon-P and incubated with either polyclonal ERK2 antisera or polyclonal Stat3 antisera as described above. Detection was with ECL.

\section{Transient transfections and CAT assays}

For transient transfection experiments, A14 cells were seeded at $2.0 \times 10^{5}$ cells per well in 6 -well plates and $24 \mathrm{~h}$ later transfected with $10 \mu \mathrm{g}$ of plasmid DNA containing a mixture of CAT-reporter, expression plasmid and pSV-lacZ control by the calcium phosphate precipitation technique. The following day the media was refreshed and cells grown for a further $8 \mathrm{~h}$. Cells were washed twice with PBS and media changed to DMEM supplemented with $0.5 \%$ FCS $\mathrm{O} / \mathrm{N}$. Inhibitors were pre-incubated for $30 \mathrm{~min}$ and insulin added for $6-8 \mathrm{~h}$. Samples were harvested and CAT assays performed on $\beta$-galactosidase corrected samples as described before (Coffer et al., 1994).

\section{Gel retardation assays}

Nuclear extracts were prepared from unstimulated and stimulated A14 cells following a previously described procedure (Andrews and Faller, 1991). pIRE(IC): 5'-agcttAGGTTTCCGGGAAAGCAc-3'; pmIRE(IC): 5'-AGGCGCGAGGTTAGCGGTCAAGCAGCACCGC - 3'; $\alpha_{2}-\mathrm{M}$ :
5'-gatcCTTCTGGGAATTCCTA-3' and SIE 5'-agcttCAGTTCCCGTCAATCc-3' oligonucleotides were synthesised and double-stranded oligonucleotides prepared by annealing the complementary strands. Oligonucleotides were labelled by filling in the cohesive ends with $\alpha^{32} \mathrm{P}$-dCTP using the Klenow fragment of DNA polymerase I. DNA fragments were separated from unincorporated oligonucleotides by polyacrylamide gel electrophoresis. Gel retardation assays were carried out according to published procedures (Fried and Crothers, 1981). Briefly, $5 \mu \mathrm{g}$ nuclear extract was incubated in a final volume of $20 \mu \mathrm{l}$, containing $10 \mathrm{mM}$ HEPES pH 7.8, $50 \mathrm{mM} \mathrm{KCl}, 1 \mathrm{~mm}$ EDTA $5 \mathrm{mM} \mathrm{MgCl}_{2}, 10 \%$ (v/v) glycerol, $5 \mathrm{mM}$ dithiothreitol, $2 \mu \mathrm{g}$ poly(dl-dC) and $20 \mu \mathrm{g}$ bovine serum albumin with $0.1-1.0 \mathrm{ng}{ }^{32} \mathrm{P}$-labelled pIRE oligonucleotide for $20 \mathrm{~min}$ at room temperature. In some experiments excess cold oligonucleotides were first added for $10 \mathrm{~min}$ at $4^{\circ} \mathrm{C}$. Subsequently, samples were run for $2 \mathrm{~h}$ on a $5 \%$ nondenaturing polyacrylamide gel at room temperature, vacuum dried and exposed to Fuji $\mathrm{RX}$ film at $-70^{\circ} \mathrm{C}$ for $1-2$ days.

\section{Recombinant vaccinia virus infections}

Vaccinia virus infections were performed essentially as described in de Vries-Smits et al. (1995). In brief, recombinant viruses, vv-wt and $\mathrm{vv}$ - $\operatorname{Ras}^{\mathrm{Asn} 17}$ were grown in $\mathrm{HeLa}$ cells (titre: $10^{9}$ virus particles per $\mathrm{ml}$ ). Semi-confluent $10 \mathrm{~cm}$ dishes of A14 cells were infected with 10 p.f.u. recombinant or wild-type virus in serum-free medium. After 60 min the medium was replaced and cells were kept in DMEM supplemented with $0.5 \%$ FCS and $10 \mathrm{~mm}$ hydroxyurea to block DNA synthesis and late viral gene expression. After $16 \mathrm{~h}$ the cells were incubated with insulin $(1 \mu \mathrm{g} / \mathrm{ml})$ for $15 \mathrm{~min}$ and duplicate dishes harvested either for gel retardation analaysis or ERK Western blotting as previously described.

\section{Measurement of ERK1 activity}

A14 cells were seeded per $5 \mathrm{~cm}$ dish in DMEM supplemented with $10 \%$ FCS and transfected with epitope-tagged HA-ERK1 (Burgering and Coffer, 1995) as described above. After stimulation, cells were washed twice in ice-cold PBS and lysed in $50 \mathrm{~mm}$ Tris- $\mathrm{Cl} \mathrm{pH} \mathrm{75,}$ $100 \mathrm{~mm} \mathrm{NaCl}, 50 \mathrm{~mm} \mathrm{NaF}, 5 \mathrm{~mm}$ EDTA, $40 \mathrm{~mm} \beta$ glycerophosphate, $1 \mathrm{~mm}$ sodium orthovanadate, $1 \% \mathrm{TX}$ $100,0.1 \mu \mathrm{M}$ aprotinin and $1 \mathrm{mM}$ PMSF. Lysates were precleared for $30 \mathrm{~min}$ at $4{ }^{\circ} \mathrm{C}$ with protein A-sepharose and HA-MAP kinase immunoprecipitated with $12 \mathrm{CA} 5$ coupled to protein A-sepharose for $2 \mathrm{~h}$ at $4{ }^{\circ} \mathrm{C}$. After washing twice with lysis-buffer, samples were washed twice with kinase buffer without ATP. Precipitates were then incubated in $25 \mu$ l kinase buffer: $30 \mathrm{mM}$ Tris-Cl $\mathrm{pH} 8.0,20 \mathrm{mM} \mathrm{MgCl}_{2}$, $2 \mathrm{mM} \mathrm{MnCl}, 10 \mu \mathrm{M}$ rATP, $7.5 \mu \mathrm{g}$ myelin basic protein and $0.3 \mu \mathrm{Ci}\left[\gamma^{32} \mathrm{P}\right] \mathrm{ATP}$ for $20 \mathrm{~min}$ at $30^{\circ} \mathrm{C}$. Reaction was stopped by the addition of $5 \times$ Laemmli sample buffer. Samples were separated by electrophoresis on $15 \%$ SDSpolyacrylamide gels. MBP phosphorylation was detected by autoradiography.

\section{Acknowledgements}

Many thanks to colleagues at the Hubrecht Laboratory, Dept. of Pulmonary Diseases and Physiological Chemistry for helpful discussions. AvP is supported by a grant from the Netherlands Organisation for Scientific Research (NWO), while PJC and BMThB are both supported by a grant from the Dutch Cancer Society (KWF). 
Allessi DR, Cuenda A, Cohen P, Dudley DT and Saltiel AR. (1995). J. Biol. Chem., 270, $27489-27494$.

Andrews NC and Faller DV. (1991). Nucleic Acids Res., 19, 2499.

Binetruy B, Smeal T and Karin M. (1991). Nature, 351, 122 127.

Boulton TG, Zhong Z, Wen Z, Darnell JE, Stahl N and Yancopolous GD. (1995). Proc. Natl. Acad. Sci. USA, 92, 6915-6919.

Burgering BM Th, Medema RH, Maassen JA, van de Wetering M, van der Eb AJ, McCormick F and Bos JL. (1991). EMBO J., 10, 1103-1109.

Burgering BM, Pronk GJ, Medema JP, van der Voorn L, de Vries-Smits AM, van Weeren PC and Bos JL. (1993). Biochem. Soc. Trans., 21, 888-894.

Burgering BM Th and Coffer PJ. (1995). Nature, 376, 599602.

Caldenhoven E, Coffer PJ, Yuan JP, van de Stolpe A, Horn F, Kruijer W and van der Saag PT. (1994). J. Biol. Chem., 269, 21146-21154.

Carlesso N, Frank DA and Griffin JD. (1996). J. Exp. Med., 183, $811-820$.

Campos SP and Baumann H. (1992). Mol. Cell. Biol., 12, $1789-1797$.

Ceresa BP and Pessin JE. (1996). J. Biol. Chem., 271, $12121-$ 12124

Chou CK, Dull TJ, Russell DS, Gherzi R, Lebwohl D, Ullrich A and Rosen O. (1987). J. Biol. Chem., 12, 1842 1847.

Coffer PJ, de Jonge M, Mettouchi A, Binetruy B, Ghysdael J and Kruijer W. (1993). Oncogene, 9, 911-921.

Coffer PJ and Kruijer W. (1995). Biochem. Biophys. Res. Commun., 210, 74-81.

Coffer PJ, Burgering BM Th, Peppelenbosch MP, Bos JL and Kruijer W. (1995a). Oncogene 11:561-569.

Coffer PJ, Lutticken C, van Puijenbroek A, Klop-de Jonge M, Horn F and Kruijer W. (1995b). Oncogene, 10, $985-$ 994.

Danial NN, Pernis A and Rothman PB. (1995). Science, 269, $1875-1877$.

David M, Petricoin III E, Benjamin C, Pine R, Weber MJ and Larner AC. (1995). Science, 269, 1721 - 1723.

Deng T and Karin M. (1994). Nature, 371, $171-175$.

Denton RM and Tavare JM. (1995). Eur. J. Biochem., 227, $597-611$.

Derijard B, Hibi M, Wu IH, Barrett T, Su B, Deng T, Karin $\mathrm{M}$ and Davis RJ. (1994). Cell, 76, $727-736$.

Dudley DT, Pang L, Decker SJ, Bridges AJ and Saltiel AR. (1995). Proc. Natl. Acad. Sci. USA, 92, 7686-7689.

Fried M and Crothers DM. (1981). Nucleic Acids Res., 9, $6505-6525$.

Galang CK, Der CJ and Hauser CA. (1994). Oncogene, 9, $2913-2921$.

Giovane A, Pintzas A, Maira SM, Sobiesczuk P and Wasylyk B. (1994). Genes Dev., 8, $1502-1513$.

Greenlund AC, Morales MO, Viviano BL, Yan H, Krolewski J and Schreiber RD. (1995). Immunity, 2, $677-687$.

Gupta S, Campbell D, Derijard B and Davis RJ. (1995). Science, 267, 389-393.

Heidenrich KA, Zeppelin T and Robinson LJ. (1993). J. Biol. Chem., 268, $14663-14670$.

Hill CS and Treisman R. (1996). EMBO J., 15, 5037-5047.

Horn F, Wegenka UM, Lütticken C, Yuan J, Roeb E, Boers W, Buschmann J and Heinrich PC. (1994). Ann. N. Y. Acad. Sci., 73, 308-323.

Hou XS, Melnick MB and Perrimon N. (1996). Cell, 84, $411-419$.

Ihle JN. (1996a). Cell, 84, $331-334$.

Ihle JN. (1996b). BioEssays, 18, $95-98$.
Jhun BH, Haruta T, Meinkoth JL, Leitner W, Draznin B, Saltiel AR, Pang L, Sasoaka T and Olefsky JM. (1995). Biochemistry, 34, 7996-8004.

Kyriakis JM, Banerjee P, Nikolakaki E, Dai T, Rubie EA, Ahmad MF, Avruch J and Woodgett JR. (1994). Nature, 369, $156-160$.

Lee J and Pilch PF. (1994). Am. J. Physiol., 266, 319-334.

Leaman DW, Pisharody S, Flickinger TW, Commane MA, Schlessinger J, Kerr IM, Levy DE and Stark GR. (1996). Mol. Cell. Biol., 16, 369-375.

Lütticken C, Coffer P, Yuan JP, Schwartz C, Caldenhoven E, Schindler C, Kruijer W, Heinrich PC and Horn F. (1995). FEBS Letts., 360, $137-143$.

Marais R, Wynne J and Treisman R. (1993). Cell, 73, 381 393.

Medema RH, de Laat WL, Martin GA, McCormick F and Bos JL. (1992). Mol. Cell. Biol., 12, 3425-3430.

Medema RH and Bos JL. (1993). Crit. Rev. Oncog., 4, 615661.

Medema RH, de Vries-Smits AM, van der Zon GCM, Maassen JA and Bos JL. (1993). Mol. Cell. Biol., 13, 155162.

Minden A, Lin A, McMahon M, Lange-Carter C, Derijard B, Davis RJ, Johnson GL and Karin M. (1994). Science, 266, $1719-1723$.

Miller BS, Shankavaram UT, Horney MJ, Gore ACS, Kurtz DT and Rosenzweig SA. (1996). Biochemistry, 35, $8769-$ 8775.

Muller M, Briscoe J, Laxton C, Guschin D, Ziemiecki A, Silvennoinen O, Harpur AG, Barbieri G, Witthuhn BA, Schindler C, Pelligrini S, Wilks AF, Ihle JN, Stark GR and Kerr IM. (1993). Nature, 366, 129-135.

Nakajima T, Kinoshita S, Sasagawa T, Sasaki K, Naruto M, Kishimoto T and Akira S. (1993). Proc. Natl. Acad. Sci. USA, 90, 2207-2211.

Olson AL and Pessin JE. (1994). Endocrinology, 134, $271-$ 276.

Ouwens DM, van der Zon GC, Pronk GJ, Bos JL, Möller W, Cheatham B, Kahn CR and Maassen JA. (1994). J. Biol. Chem., 269, 33116-33122.

Pawson T. (1995). Nature, 373, 573-580.

Pfeffer LM, Mullersman JE, Pfeffer SR, Murti A, Shi W and Yan CH. (1997). Science, 276, 1418-1420.

Pronk GJ, Medema RH, Burgering BM Th, Clark R, McCormick F and Bos JL. (1992). J. Biol. Chem., 267, $24058-24063$.

Pronk GJ, McGlade J, Pelicci G, Pawson T and Bos JL. (1993). J. Biol. Chem., 268, 5748-5753.

Pronk GJ, de Vries-Smits AM, Buday L, Downward J, Maassen JA and Bos JL. (1994). Mol. Cell. Biol., 14, $1575-1581$.

Pulverer BJ, Kyriakis JM, Avruch J, Nikolakaki E and Woodgett JR. (1991). Nature, 353, 670-674.

Quelle FW, Thierfelder W, Witthuhn BA, Tang B, Cohen S and Ihle JN. (1995). J. Biol. Chem., 270, 20775-20780.

Robertson LM, Kerppola TK, Vendrell M, Luk D, Smeyne RJ, Bocchiaro C, Morgan JI and Curran T. (1995). Neuron, 14, 241-252.

Rosen OM. (1987). Science, 237, $1452-1458$.

Roth RA, Zhang B, Chin JE and Kovacinak. (1992). J. Cell. Biochem., 48, $12-18$.

Sanchez I, Hughes RT, Maer BJ, Yee K, Woodgett JR, Avruch J and Kyriakis JM. (1994). Nature, 372, 794-798.

Seth A, Gonzalez FA, Gupta S, Raden DL and Davis RJ. (1992). J. Biol. Chem., 267, 24796-24804.

Schindler C and Darnell JE. (1995). Ann. Rev. Biochem., 64, $621-651$

Schindler U, Pengguang W, Rothe M, Brasseur M and McKnight SL. (1995). Immunity, 2, 689-697. 
Shuai K, Ziemiecki A, Wilks AF, Harpur AG, Sadowski HB Gilman MZ and Darnell JE. (1993). Nature, 366, 580583.

Shuai K, Horvath CM, Huang LH, Qurehi SA, Cowburn D and Darnell JE. (1994). Cell, 76, $821-828$

Shuai K, Halpern J, ten Hoeve J, Rao X and Sawyers CL. (1996). Oncogene, 13, 247-254.

Silvennoinen O, Ihle JN, Schlessinger J and Levy DE. (1993). Science, 261, 1736-1739.

Skolnik EY, Lee CH, Batzer A, Vicentini LM, Zhou M, Daly R, Myers MJ, Backer JM, Ullrich A, White MF and Schlessinger J. (1993). EMBO J., 12, 1929-1936.

Stahl N, Farruggella TJ, Boulton TG, Zhong Z, Darnell JE and Yancopoulos GD. (1995). Science, 267, 1349-1353.

Su B, Jacinto E, Hibi M, Kallunki T, Karin M and BenNeriahy. (1994). Cell, 77, 727-736.

Sun XJ, Rothenberg P, Kahn CR, Backer JM, Araki E, Wilden PA, Cahill DA, Goldstein BJ and White MF. (1991). Nature, 352, 73-77.

Sun XJ, Crimmins DL, Myers MG, Montserrat $\mathrm{M}$ and White MF. (1993). Mol. Cell. Biol., 13, 7418-7428.

Vignais ML, Sadowski HB, Watling D, Rogers NC and Gilman M. (1996). Mol. Cell. Biol., 16, 1759-1769.

de Vries-Smits AM, Burgering BM Th, Leevers SJ, Marshall CJ and Bos JH. (1992). Nature, 357, 602-604. de Vries-Smits AM, Burgering BMTh and Bos JL. (1995). Methods Enzymol., 255, 221 - 230.

Watling D, Guschin D, Muller M, Silvennoinen O, Witthuhn BA, Quelle FW, Rogers NC, Schindler C, Stark GR, Ihle JN and Kerr IM. (1993). Nature, 366, 114-116.

Weber-Nordt RM, Egen C, Wehinger J, Ludwig W, Gouilleux-Gruart V, Mertelsmann $\mathrm{R}$ and Finke J. (1996). Blood, 88, 809-816.

Wen Z, Zhong Z and Darnell JE. (1995). Cell, 82, 241-250.

Wymann MP, Bulgarelli-Leva G, Zvelebil MJ, Pirola L, Vanhaesebroeck B, Waterfield MD and Panayatou G. (1996). Mol. Cell. Biol., 16, $1722-1733$.

Yan R, Small S, Despian C, Dearolf CR and Darnell JE. (1996). Cell, 84, 421-430.

Yu CL, Meyer DJ, Campbell GS, Larner AC, Carter-Su C, Schwartz J and Jove R. (1995). Science, 269, 81-83.

Yuan J, Wegenka UM, Lütticken C, Buschmann J, Decker T, Schindler C, Heinrich PC and Horn F. (1994). Mol. Cell. Biol., 14, 1657-1668.

Zhang X, Blenis J, Li HC, Schindler C and Chen-Kiang S. (1995). Science, 267, 1990-1994.

Zhong Z, Wen Z and Darnell JE. (1994). Science, 264, $95-$ 98. 